\title{
建物火災に伴う火の粉の飛散と AN INVESTIGATION ON THE 飛び火に関する実態調查 DISTRIBUTION OF FIRE BRANDS AND SPOT FIRES DUE TO A HOTEL FIRE
}

\section{大宮喜文 一 $* 1 \quad$ 岩見達也 $-* 2$}

キーワード

火の粉, 飛び火, 実地調査, アンヶート調査, ホテル火災

Keywords

Fire brand, Spot fire, Exploration, Survey on questionnaire, Hotel fire
Yoshifumi OHMIYA $-* 1 \quad$ Tatsuya IWAMI $-* 2$

A hotel fire occurred in Shirahama, Wakayama prefecture on November 17th 1998. This building fire was one of the widest burning area of building fires in Japan. During this fire, there was high wind velocity at about $7 \mathrm{~m} / \mathrm{sec}$. At the same time, there was a lot of number of fire brands. We surveyed the distribution of fire brands and spot fires due to this fire by exploration and questionnaire. As a consequence, it was found that through exploration and questionnaire that there is a relation between the distribution of fire brands and the size of fire brands etc.

\section{1.はじめに}

建築物で火災が発生し延焼拡大していくと、建物部材や収納家具 などの燃え殼の一部が火の粉となり高温の熱気流とともに舞い上が り、火元建物周辺へ飛散する。気象条件によっては、火の粉の飛散 距離が数キロに及ぶ場合もある。このような火の粉の飛散および火 の粉を原因とした飛び火に関する調査結果は、過去に幾つか報告さ れている1)。それら報告の多くは、火の粉の飛散範囲、および飛び 火箇所について調査されたものが多く、火の粉の飛散範囲および飛 び火は、風速などの気象条件や火元付近の地形などと関係すること を明らかにしている21。しかし、火の粉の飛散範囲や飛び火は、火 元建物の火源の大きさや火の粉の発生量などとも何らかの相関性が あるものと考えられるが、これまでその点を考慮したかたちで実態 調査はほとんど行われていない。

そのような背景のもと、1998 年 11 月 17 日、広範囲にわたり火 の粉が飛散した火災が和歌山県白浜温泉（和歌山県西牟婁郡白浜町 ホテル天山閣）において発生した。折しも火災発生当時、火元とな ったホテルのある地域では海から内陸への強風が吹いていた。それ がホテルの火災拡大を助長させる結果となったばかりでなく、焼失 面積も単体建築物としては大規模なものとなり、多量の火の粉を発 生する火災に至った。そこで本稿では、火の粉の発生から着床まで の一連の性状と飛び火の被害を把握するため、筆者らが現地調査お よびアンケート調査(備考) を行ったので、その結果について報告する。

\section{2. 火災概要 ${ }^{3)}$ 4)}

図 1 に示した通り、䍜災したホテルの建物は、RC 造、S 造、木 造が混在した複雑な配置となっており、延べ面積は $12,589 \mathrm{~m}^{2}$ であ った。火災当時、海から内陸へ南南東の方向へ強風が吹いており、 出火場所（推定）が火元ホテルの風上側であったこともあり、ホテ ル風下方向へ延焼拡大し、12,000 $\mathrm{m}^{2}$ 程度（調査中）の焼損面積とな った。特に別館の木造建築物が炎上している際、多量の火の粉が発

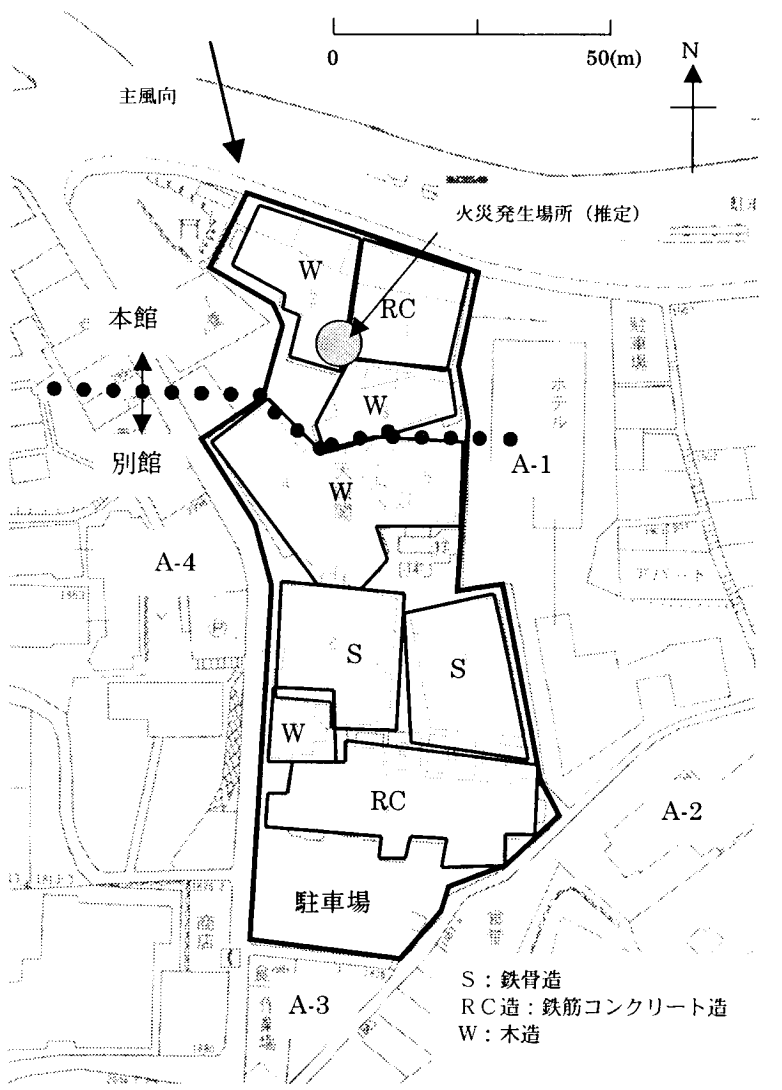

図 1 火元建物の配置と周辺の概要図

生した。この火災の発生から鎮火に至るまでの時間経過は以下の通 りである。

出火日時: 平成 10 年 11 月 17 日 $18: 00$ 頃（調查中）

覚知日時: 平成 10 年 11 月 17 日 $18: 38$

鎮火日時: 平成 10 年 11 月 18 日 $6: 00$

そして、火災発生から鎮火に至るまでのこの地域の気象条件を整理

\footnotetext{
*1 建設省建築研究所第 5 研究部 研究員 - 工博

(干305-0802 茨城県つくば书立原1)

*2 建設省建築研究所第 6 研究部 研究貣 · 工修
}

*1 Research Engineer, Building Research Institute, MoC, Dr. Eng. (Tatehara 1, Tukuba-shi, Ibaraki)

*2 Research Engineer, Building Research Institute, MoC, M. Eng. 
したものが図 2 である。図2からも分かるとおり、火災現場付近（観 測場所：白浜町消防本部、図 3 参照）で記録された風速は $7 \mathrm{~m} / \mathrm{s}$ 前 後であり、和歌山地方気象台により強風波浪注意報も発令されてい た。新聞によっては最大約 $18 \mathrm{~m} / \mathrm{s}$ 前後の風速であったとの報道も ある。また写真 1 の通り、火元ホテル付近では、海岸線から傾斜し た段々状の地形の上に建築物が混在しており、その地形も高低差が 入り組む複雑なものとなっている。そのため風向や風速もその地形 に大きく影響を受けるものと考えられる。

\section{3. 火の粉の飛散範囲と飛び火の被害状況}

図 2 に示したとおり、火災発生当時、7m 前後の強風であったこ ともあり、火の粉が広範囲にわたって飛散し、飛び火の被害が発生 した。ここでは、火の粉の飛散状況と火の粉による飛び火の発生状 況について現地調査の結果を示す。

\section{1 火元近隣建築物への火の粉の被害}

火元ホテルの近隣建築物に対する火の粉の飛散状 洗をまず整理する。火元ホテルと東側に隣接するホテ ル(A-1)の間に幅約 $1 \mathrm{~m}$ の歩道があるが、この歩道上 に多くの火の粉が確認され、特に火元ホテル別館の木 造に接する歩道部分では大小様々な火の粉が多量に確 認された。また火元ホテル別館の東側に位置する保養 所（A-2）は、その外壁面および空ガラス面にすすが 付着し、庭には多量の火の粉が確認された。火災当時、 この保養所（A-2）は火元建物に対し風下側に位置し たため、大量の煙や火の粉が激しく壁や㤵に吹き付け たことが推測できる。また、ホテル南側の木造住宅 （A-3）の火元に面する壁付近に多量の粉状の火の粉 が確認された。そしてホテル西側の住宅や商店(A-4) と火元との間の $4 \mathrm{~m}$ 道路上にも火の粉が確認され、こ れら住宅や商店 $(\mathrm{A}-4)$ へは、数十 $\mathrm{cm}$ 前後の大きさの 火の粉が飛来していたという証言が得られた。以上の 現地調查の結果、火元ホテル周辺の建物へは、北側を 除く全ての方向に火の粉が飛散していたことが分かっ た。また、消防や住民による消火活動等が奏功し、こ れら火の粉による顕著な飛び火の被害は確認されなか った。

\section{2 火の粉の飛散範囲}

図 3 は、火の粉の飛散範囲と飛び火地点を示したも のである。図 3 より火災発生当時、南南東の方向を中 心に強風が吹いており、火の粉はその風下方向を中心 として広範囲にわたり飛散したことがわかる。図 3 に よれば、火の粉が確認された火災現場からの最長距離 は、水平投影直線距離にして約 $850 \mathrm{~m}$ 、高低差は約 $100 \mathrm{~m}$ の地点であった。また火の粉が飛散した最大幅 は約 $500 \mathrm{~m}$ であり、飛散角度は 85 度程度（火災現場 の最も風上側を起点とした場合）となった。図 2 の風 向から考えると、火の粉の飛散が火元ホテルの東側方 向に偏る傾向にあることがわかる。これはこの地域の 地形的な要因が影響し、図 2 に示した一定の方向に必 ずしも風が吹いていなかったことが考えられる。また、

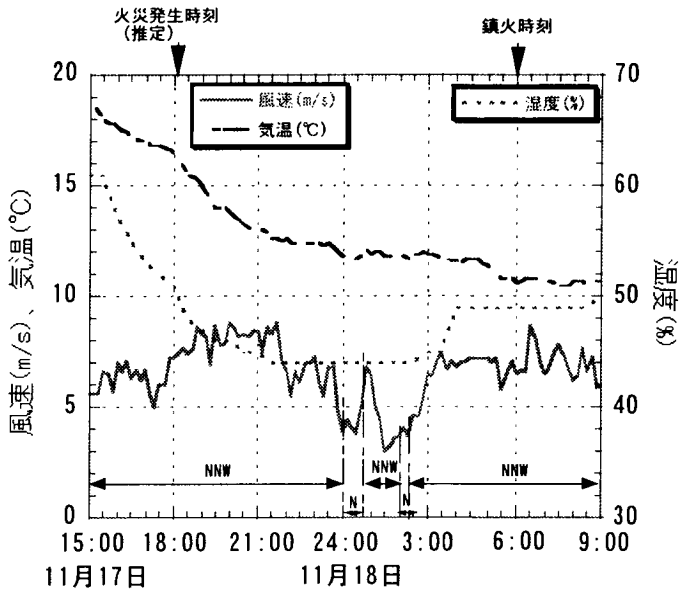

注）NNWは北北西、Nは北からの風位を示す。

図 2 火災発生時の気象条件

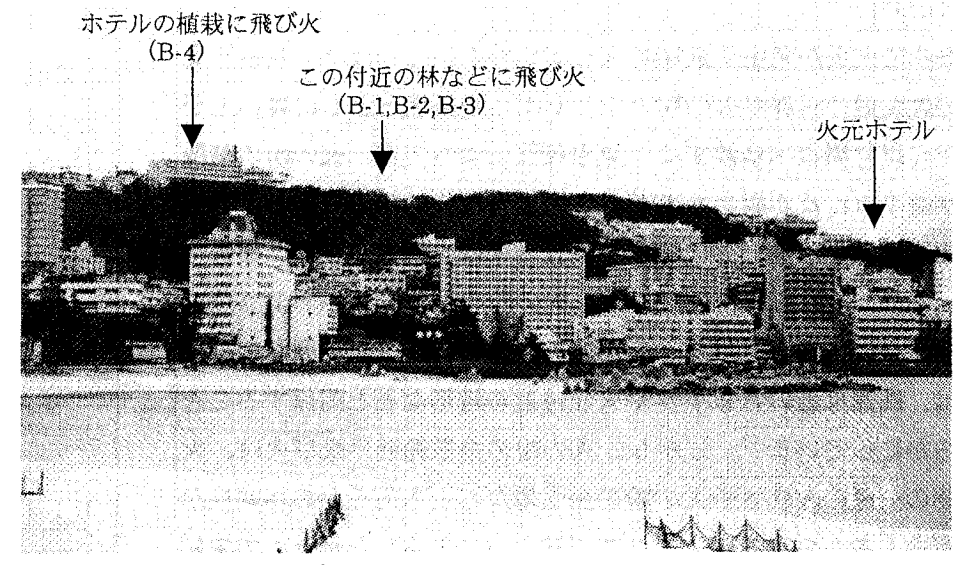

写真 1 火災現場付近の遠景

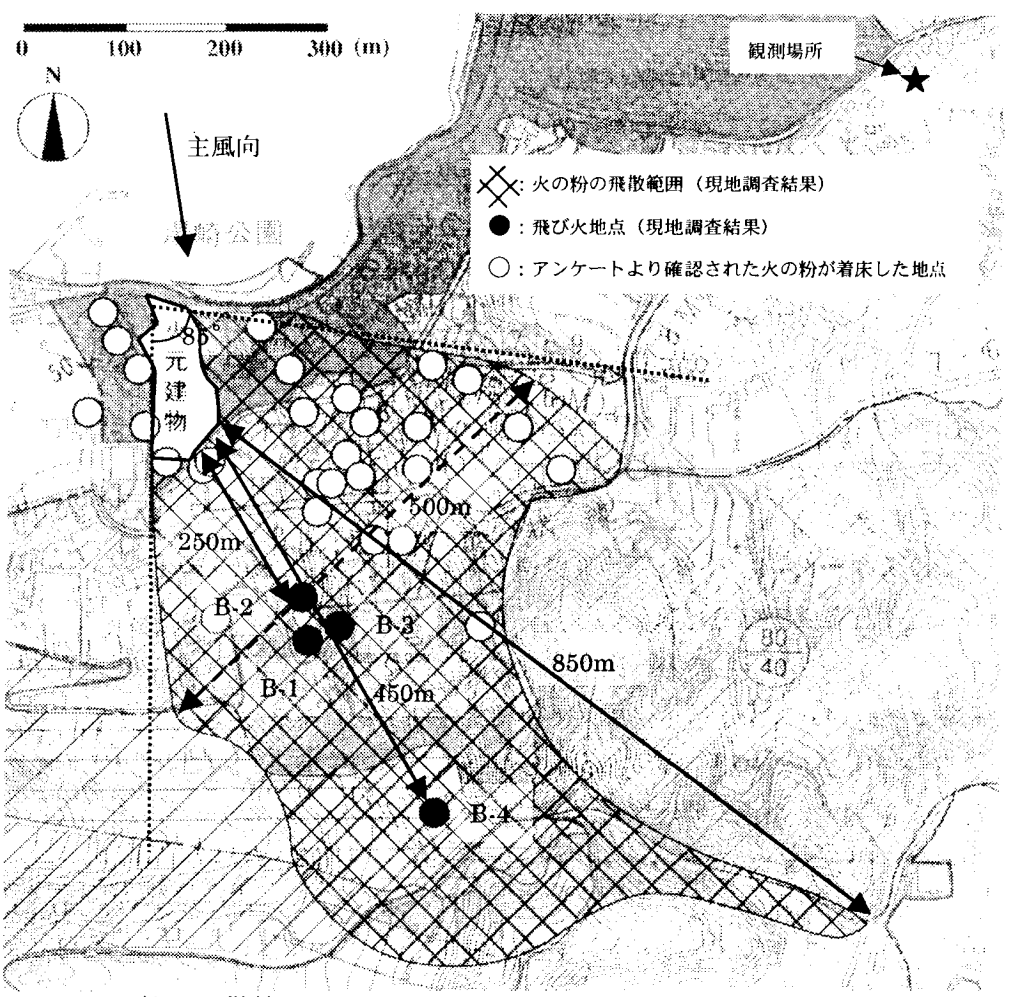

図 3 火の粉の飛散範囲 
火元建物の風下方向に約 $200 \mathrm{~m}$ までの範囲では、火の粉やその燃 えかすが “粉雪” のように降り注いでいたとの証言も得られた。

3. 3 火の粉による飛び火の被害

火の粉により、火元ホテルから南東に約 $250 \mathrm{~m}$ 離れたところにあ る保養所（B-1）と住宅（B-2）の植栽に飛び火したことが現地調 査で確認された（図 3 および写真 1 ）。また、それら保盖所と住宅 に面する林（B-3）では、飛び火により約 $100 \mathrm{~m}^{2}$ が燃えている。 さらに、火元建物から南東方向に約 $450 \mathrm{~m}$ 離れたホテル（B-4）の 樹木にも飛び火し、これも消防によって消火されている。火災当時、 このホテルにも断続的に激しく強風が吹きつけており、ホテルバル コニ一では風上方向に歩いて進むには前届みにならなければならな い程の強風であった様である。その状況から風速は $20 \mathrm{~m} / \mathrm{s}$ 前後で あったものと推定される ${ }^{5)}$ 。これ程の強風になったのも、このホテ ルが火元建物からの風が絞り込まれる谷の上方に位置していたため と考えられる。

\section{4.アンケート調査}

火災発生から 2 ケ月後、この火災における火の粉の飛散に関する アンケート調査を行った。アンケート調査では、火の粉の発生から 着床までの一連の性状、および飛び火の被害について把握すること を目的とした。

\section{1 方法および内容}

火の粉に関するアンケート調査の対象者は、火元ホテルの関係者 とその周辺住民である。火元ホテルの関係者については、火災発生 当日ホテルに勤務していた人、40 名を対象とし、集合調查の形式 を採った。また、火元ホテルの周辺住民に対しては、郵送調査と面 接調査の形式を採用した。郵送調査は、周辺住民 249 世帯にアンケ 一ト用紙を送付し、52 世帯について回収することができ、回収率 は約 $21 \%$ \%゙る。また面接調査では、郵送調查対象以外の周辺住 民を対象とし、直接現地で 8 名からアンケートの回答を得た。

アンケートの内容は大別して、「火元建物の火災の状況」、「火の 粉の性状」、および「飛び火の被害」について回答を求め、設問は 選択形式中心の構成とした。

4. 2 アンケート結果

1）火の粉の発生状況

図 4 は、火の粉の発生状況を把握するため、火の粉が発生した 時の大きさと量について回答を求めた結果である。この結果より、

$\lceil 5 \mathrm{~cm}$ 以下」の大きさの火の粉が「多量」に発生していたという回 答が最も多かった。また、火の粉が多量に発生した時期については、 木造建築物が炎上している時という回答が最も多かった。

図 5 は、火の粉が発生した時の火源の平均火炎高さと代表幅に ついて整理した結果である。この結果より、平均火炎高さは約 $10 \mathrm{~m}$ 、 火炎の代表幅は約 20m という回答が最も多かった。

図6は、火の粉が垂直高さ方向にどの程度上昇したかについて、 火の粉の垂直方向への最高高さとその火の粉の上昇高さから平均火 炎高さを引いた結果を整理したものである。この結果より、火の粉 の垂㨁方向への上昇高さは、 $15 \mathrm{~m}$ から $20 \mathrm{~m}$ という回答が最も多い 結果となった。また、その火の粉の上昇高さから平均火炎高さを引 いた高さは、約 $10 \mathrm{~m}$ という回答が最も多い結果となった。徒って、 火元付近では火の粉は、平均火炎高さの約 2 倍の高さまで舞い上が

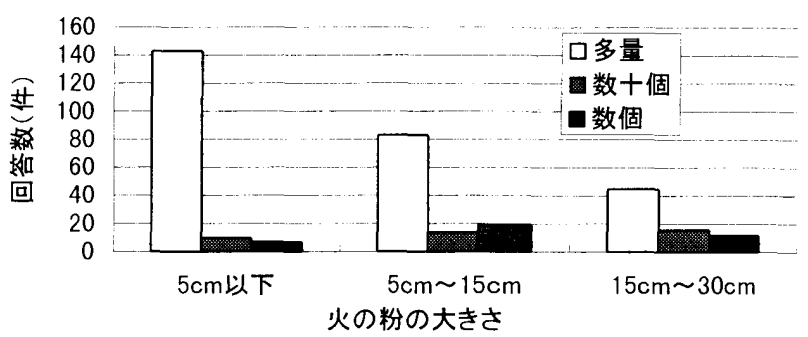

図 4 火の粉の大きさと発生量

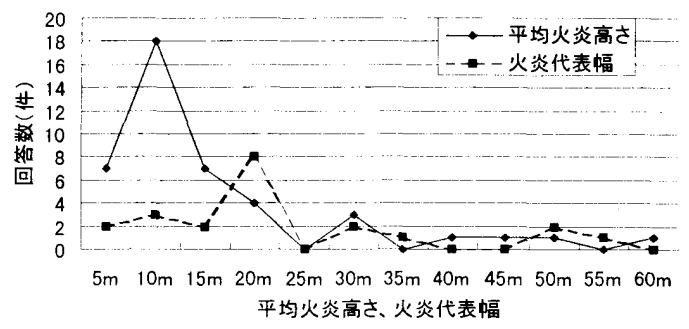

図 5 平均火炎高さと代表幅

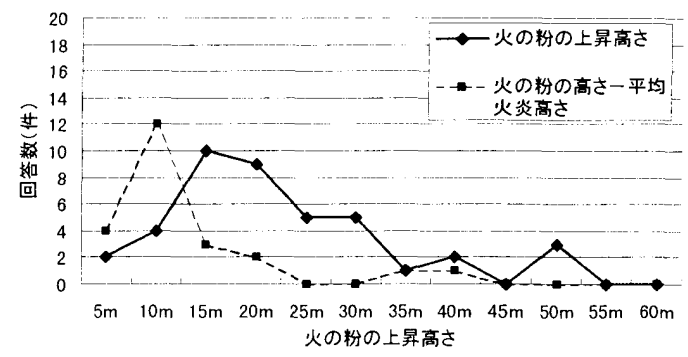

図 6 火の粉の上昇高さ

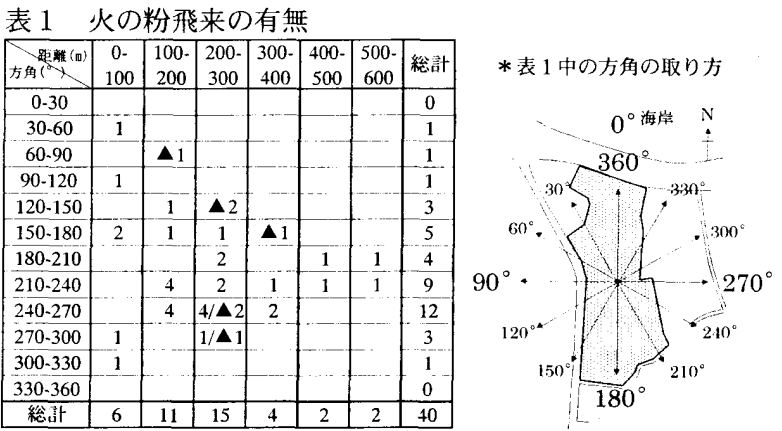

りながら風下方向へ飛散していったこととなる。

2 ）火の粉の飛散状況

表 1 は回答者の位置と火の粉飛来の有無との関倸を示したもので ある。表中にある「ム」の後の数字は飛来なしと回答した数であ り、その他の数字は飛来ありと回答した数である。また、有効回答 について、回答者の位置を用いて火元ホテルの中央部からの距離と 方角を求めた。方角については、北を 0 度とし、反時計回りに計測 している。表 1 の結果より、0〜100m の範囲で、概ね全方向に火の 粉が飛散しているが、距離が離れるにつれ、飛散方向は徐々に、180 度〜240 度の方向に絞られることがわかる。この結果より、火元付 近では風向に関係なく概ね全方角へ火の粉は飛散するが、火元から 遠のくに連れ、風の影響を受けることがわかる。またアンケート結 果から得られた火の粉の飛散範囲は、図 3 で示した実地調査の結果 と概ね一致することが分かる。 
表 2 は、「粉状」を $1 、 「 5 \mathrm{~cm}$ 程度」を $5 、 「 15 \mathrm{~cm}$ 程度」を 15、「 $30 \mathrm{~cm}$ 程度」を 30 として、サンプルごとに飛来して きた最大の火の粉の大きさを求め、回答者の位置ごとに平 均をとり整理した結果である。表 2 より火元ホテルからの 距離が長くなるほど、火の粉は小さくなる傾向が伺える。 $200 \mathrm{~m}$ 程度までは、大きな火の粉が比較的多く見られ、 $500 \mathrm{~m}$ を越えると粉状のもののみが確認されている。

図 7 は火の粉の形状ごとの飛散量および飛来した最大の 火の粉の大きさの分布を示したものである ${ }^{61}$ 。火元ホテル から南東の方角の $300 \mathrm{~m}$ 程度の範囲内では、すべての形状 の火の粉が多量に確認され、粉状の火の粉は広範囲に飛散 していることが分かる。また、火の粉の大きさごとの飛散範囲は、 火の粉の大きさが小さくなるほどその飛散範囲は風下方向に拡大し ており、図 4 で示した火の粉の大きさ毎の発生量や風速と相関して いるものと推測できる。

\section{3 ）飛び火性状}

表 3 は火の粉による飛び火の発生した場所を整理した結果であ る。飛び火の被害は、火元ホテルから $200 \mathrm{~m}$ 以内の範囲で多く発生 しており、200m 以内のアンケート回答者の $39.1 \%$ 人が飛び火の被 害を受けたと回答している。また、火元ホテルの風下方向では $400 \mathrm{~m}$ 以上離れた位置にも飛び火の被害が及んでいる。なお、火元に極め て近くの回答者の中には、被害はなかったが消防による放水によっ て被害を免れたという回答もあった。表 2 と表 3 の結果を照らし合 わせると、 $1 \mathrm{~cm}$ を超える大きさの火の粉が飛散する範囲では、飛び 火の発生する可能性があったことがわかる。

\section{5.まとめ}

和歌山県白浜温泉で発生した火災による火の粉の飛散範囲およ び飛び火被害を調査するため、実地調査とアンケート調査を行った。

実地調査から火の粉の飛散範囲については、風向がその範囲に 大きく影響すること、特に地形が複雑なところでは、その地形が風 速や風向を変化させるため、火の粉の飛散範囲に大きく影響するこ となどが確認された。今回の実地調査の結果、火の粉の最長飛散距 離は約 $850 \mathrm{~m}$ となり、火元建物を中心とした火の粉の飛散角度は、 約 $85^{\circ}$ という結果となった。また、火の粉による樹木への飛び火 が数例確認され、樹木への飛び火の危険性が高いことも確認された。

さらに火の粉の飛散から着床に至るまでの一連の性状を把握す るためアンケート調査を行った。まず火の粉の発生元である火源の 大きさ、および火元付近での火の粉の発生量とその大きさの関倸に ついて整理した。その結果、木造建築物が炎上している際に火の粉 の大きさが小さいものほど多量に発生する傾向にあることがわかっ た。また、火の粉の形状とその大きさによる飛散範囲および飛び火 の被害を明らかにし、火の粉の飛散範囲については、概ね実地調査 と同様の結果が得られた。そして、 $1 \mathrm{~cm}$ を超える大きさの火の粉が 飛散する範囲では、飛び火の発生する可能性があり、特に火元から $200 \mathrm{~m}$ 以内の範囲では、飛び火の被害が多かったことが明らかとな った。

今後は、火災発生当時の火元建物の写真やビデオ映像の解析を 行い、贸性状や火の粉の一連の性状について整理する予定である。
表 2 火の粉の大きさ

\begin{tabular}{|c|c|c|c|c|c|c|c|}
\hline 距整(m) & $0-$ & $100-$ & $200-$ & $300-$ & $400-$ & $500-$ & 平均 \\
\hline $0-30$ & 100 & 200 & 300 & 400 & 500 & 600 & \\
\hline $30-60$ & 30.0 & & & & & & 30.0 \\
\hline $60-90$ & & 0.0 & & & & & 0.0 \\
\hline $90-120$ & & & & & & & \\
\hline $120-150$ & & 30.0 & 0.0 & & & & 10.0 \\
\hline $150-180$ & 30.0 & 15.0 & 15.0 & 0.0 & & & 15.0 \\
\hline $180-210$ & & & 10.0 & & 1.0 & 1.0 & 5.5 \\
\hline $210-240$ & & 15.3 & 3.0 & 1.0 & 5.0 & 1.0 & 8.2 \\
\hline $240-270$ & & 1.0 & 3.0 & 8.0 & & & 3.6 \\
\hline $270-300$ & 5.0 & & 7.5 & & & & 6.7 \\
\hline $300-330$ & 1.0 & & & & & & 1.0 \\
\hline $330-360$ & & & & & & & \\
\hline 平均 & 16.5 & 12.0 & 4.9 & 4.3 & 3.0 & 1.0 & 7.6 \\
\hline
\end{tabular}

表 3 飛び火による被害

\begin{tabular}{|c|c|c|c|c|c|c|c|}
\hline 方角( & $\begin{array}{c}0- \\
100 \\
\end{array}$ & $\begin{array}{l}100- \\
200\end{array}$ & $\begin{array}{l}200- \\
300\end{array}$ & $\begin{array}{l}300- \\
400\end{array}$ & $\begin{array}{l}400- \\
500\end{array}$ & $\begin{array}{l}500- \\
600\end{array}$ & 総計 \\
\hline \multicolumn{8}{|l|}{$0-30$} \\
\hline \multicolumn{8}{|l|}{$\frac{30-60}{60-90}$} \\
\hline $60-90$ & & & & & & & \\
\hline \multicolumn{8}{|l|}{$90-120$} \\
\hline \multicolumn{8}{|l|}{$120-150$} \\
\hline $150-180$ & & & 1 & & & & 1 \\
\hline $180-210$ & 2 & & & & 1 & & 3 \\
\hline $210-240$ & & 4 & 1 & & & & 5 \\
\hline $240-270$ & 1 & 1 & & 1 & & & 3 \\
\hline \multicolumn{8}{|l|}{$270-300$} \\
\hline 300-330 & 1 & & & & & & 1 \\
\hline \multicolumn{8}{|l|}{$330-360$} \\
\hline 総計 & 4 & 5 & 2 & 1 & 1 & & \\
\hline
\end{tabular}

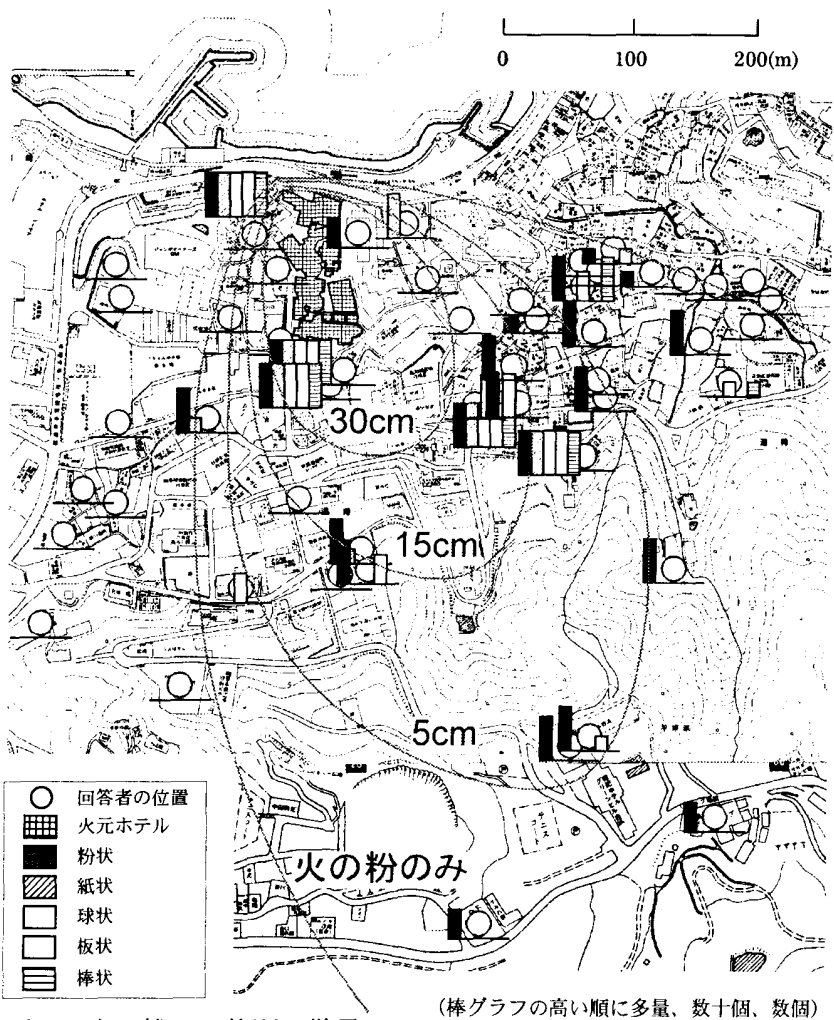

図 7 火の粉の形状別飛散量

備考）アンケート調査は、日本火災学会「地震時の出火・延焼シナ リオに関する調査委員会」（主査 : 辻本 誠）が行った火の粉に関 するアンケート調査について示したものである。

謝辞 今回の調査に際し、和歌山県、田辺市役所、白浜町消防局、 そして罹災したホテルの関倸者の方々には多大なご協力を頂いた。 また、本調査を行うにあたり、京都大学助教授原田和典氏にご指導 を頂いた。ここに記して感謝いたします。

参考文献

1）石田正次、琭本孝一：火の粉の分布に関する現地調查、火炎、第 7 巻第 1 号、 $\mathrm{p} 3 \sim 7,1957$

2）珮内三郎：建箱防火、p 191 195、1972。10

3 ) 関沢愛: 白活温泉ホテル天山閣の火災概要、火災誌 Vol.48 No.6, p49 51, 1998.12

4）近代消防編集局：和歌山県白浜温泉ホテル天山閣火災、近代消防、p39 $\sim 43,1999.2$

5 ）新建築学大系 $8 、 p 411 、 1969.5$

6) 刍井幸次郎: 大火時の飛び火の性状、火災、第 7 巻第 1 号、p15 21、1957 